\title{
PARASIT GASTROINTESTINAL PADA SAPI DI DAERAH ALIRAN SUNGAI PROGO YOGYAKARTA
}

\author{
The Gastrointestinal Parasites Cows on Progo Watershed in Yogyakarta
}

\author{
Yudhi Ratna Nugraheni1, Dwi Priyowidodo1, Joko Prastowo', Eryl Sri Rohayati1, Ana \\ Sahara ${ }^{1}$, Aan Awaludin ${ }^{2}$ \\ ${ }^{1}$ Fakultas Kedokteran Hewan, Universitas Gadjah Mada \\ 2Jurusan Peternakan, Politeknik Negeri Jember \\ Email: yudhiratnanugraheni@gmail.com
}

\begin{abstract}
INTISARI
Penelitian ini bertujuan untuk mengidentifikasi parasit gastrointestinal pada sapi yang berlokasi di daerah aliran Sungai Progo. Penelitian ini menggunakan feses sapi sebanyak 63 sampel yang diambil dari daerah aliran Sungai Progo. Pemeriksaan feses menggunakan metode sentrifuse, dan Parfitt Bank. Hasil penelitian menunjukkan bahwa 63 sampel feses sapi yang diperiksa, 25 diantaranya terinfeksi cacing jenis Fasciola sp., 7 ekor Paramphistomum sp., 14 Strongyle, dan 9 Coccidiosis. Kesimpulan dari penelitian ini adalah prevalensi parasit gastrointestinal pada sapi di aliran Sungai Progo yang dominan adalah kejadian Fasciolosis sebesar 40\%, infestasi nematodiasis jenis Strongyle 22\%, Coccidiosis 14\%, dan infestasi Paramphistomum sp.11\%.
\end{abstract}

Kata kunci: Coccidiosis, Fasciola sp., Parampistomum sp., Strongyle

\section{ABSTRACT}

The aim of study was investigate gastrointestinal disease on cow fed forage from Progo watershed. Sixty three feses samples were taken from cows on Progo watershed. The method of feses analysis used was sentrifuge and Parfitt Bank. The results showed that 63 samples of cows feces were examined, among 25 were infected by Fasciola sp., 7 Paramphistomum sp., 14 Strongyle, and 9 Coccidiosis. The conclusion was the prevalence of gastrointestinal disease in cows was dominant incidence of Fasciolosis by 40\%, Strongyle 22\%, 14\% Coccidiosis, and Paramphistomum sp.11\%.

Keywords: Coccidina, Fasciola sp., Parampistomum sp., Strongyle

\section{PENDAHULUAN}

\section{Latar Belakang}

Sapi merupakan salah satu penghasil protein hewani di Indonesia. Lokasi peternakan sapi di aliran sungai dapat berpengaruh terhadap penularan penyakit gastrointestinal salah satunya adalah Fasciolosis. Hal ini terkait dengan stadium infektif Fasciola sp. yaitu metaserkaria yang menempel pada rumput di area berair. Lahan pakan yang berasal dari dareah aliran Sungai Progo akan menjadi memungkinkan terjadi penularan parasit Fasciola melalui stadium metaserkaria.

Penyakit gastrointestinal pada sapi dapat menyebabkan kerugian ekonomi bagi peternak Indonesia. Tingkat infestasi cacing saluran pencernaan bahkan pernah dilaporkan mencapai prosentasi $80 \%$ pada sapi dengan umur kurang dari satu tahun (Widyaningrum et al., 2015). Penelitian di 
Kecamatan Sukoharjo menunjukkan infestasi cacing saluran pencernaan baik tunggal maupun campuran sebesar 83,97\%, sedangkan yang tidak terinfestasi sebesar 16,03\% (Handayani et al., 2015). Penelitian helminthiasis di provinsi Bali menunjukkan prevalensi helminthiasis secara signifikan lebih tinggi ditemukan pada sapi betina dibandingkan dengan sapi jantan (Arsani et al., 2015), sedangkan di Jawa Tengah dilaporkan tingkat infestasi sebesar 65,93\%. Parasit-parasit tersebut adalah Strongylidae (54\%), Fasciola sp. (17\%), Eimeria sp. (15,33\%), Strongyloides sp. $\quad(4,67 \%)$, Paramphistomum sp. (4\%), Trichuris sp. $(3,67 \%)$ dan Moniezia sp. (1,33\%) (Hamid et al., 2016).

Prevalensi mengenai parasit di Taiwan pernah diteliti dan hasil menunjukkan bahwa prevalensi tinggi ada pada infeksi protozoa dengan persentase $81,3 \%$ dan prosentase helminthiasis akibat nematoda 7,9\%, cestoda 1,6\% dan trematoda sebesar 0,6\% (Huang et al., 2014)

Kejadian helminthiasis saluran pencernaan pada pedet Peranakan Simental dan Limousin dipengaruhi oleh faktor pemberian obat cacing, tata laksana kandang, umur, dan jenis kelamin (Virgi et al., 2015). Nematoda yang sering menyerang sapi anakan maupun sapi dewasa adalah Cooperia sp., Bunostomum sp., Mecistocirrus sp., dan Trichuris sp. (Junaidi et al,. 2014). Trematoda dari jenis paramphistomum pernah diteliti di Kabupaten Bone di daerah Libureng angka prevalensi cacing trematoda ini mencapai
57\% dari total 100 ekor sapi (Darmin et al,. 2016). Tingginya kejadian infestasi cacing hati dipengaruhi oleh faktor tempat penggembalaan, umur, musim, dan pengobatan cacing yang tidak rutin (Handayani et al., 2015).

Sapi dewasa lebih banyak terinfestasi daripada sapi muda (Nnabuife et al., 2013). Prevalensi cacing gastrointestinal pada sapi paling sering ditemukan pada usia 1 sampai 5 tahun (Karim et al., 2016). Parasit gastrointestinal merupakan sumber permasalahan pada sapi dan kerbau di India dengan tingkat prevalensi bervariasi (Marskole et al., 2016). Faktor lingkungan yang mempengaruhi perkembangan larva 3 nematoda pada rumput diantaranya dipengaruhi oleh suhu, kelembapan, dan curah hujan (Das et al., 2016). Tujuan penelitian ini adalah untuk mengetahui keragaman parasit gastrointestinal pada sapi di daerah aliran Sungai Progo.

\section{MATERI DAN METODE}

Penelitian ini menggunakan 63 sampel feses sapi potong di lokasi dareah aliran Sungai Progo. Metode pemeriksaan menggunakan metode pemeriksaan feses secara sentrifus dan metode Parfitt Bank dilakukan di Laboratorium Parasitologi, Fakultas Kedokteran Hewan, Universitas Gadjah Mada.

Metode sentrifus dilakukan dengan cara mengambil sampel feses $1 \mathrm{~g}$ ke dalam mortar lalu dihomogenkan dengan $14 \mathrm{ml}$ air 
kemudian dimasukkan ke dalam tabung sentrifus hingga $3 / 4$ tabung. Sentrifus dilakukan pada 3000 rpm selama 10 menit, kemudian supernatan dibuang dan endapan feses ditambahkan $\mathrm{NaCl}$ jenuh hingga 3/4 tabung. Larutan tersebut diaduk dan disentrifus lagi pada dengan kecepatan dan waktu. Penambahan $\mathrm{NaCl}$ jenuh dilakukan sampai bagian permukaan berbentuk cembung. Larutan tersebut dibiarkan selama 3 sampai 5 menit supaya parasit terapung dipermukaan larutan. Penempelan object glass dilakukan pada permukaan larutan yang cembung tersebut supaya parasit menempel pada object glass dan dilakukan penutupan dengan deckglass. Pengamatan dilakukan menggunakan mikroskop (perbesaran 10 kali). Metode ini digunakan untuk mengetahui ada atau tidaknya telur cacing dan oosista sapi.

Metode Parfitt Bank dilakukan untuk mengetahui adanya telur trematoda pada feses sapi dengan penimbangan sampel feses seberat 1 g. Feses dimasukkan ke dalam mortar diberi air $20 \mathrm{ml}$, disaring, kemudian dimasukkan ke dalam tabung sampai setinggi $2 \mathrm{~cm}$ dari mulut tabung. Larutan tersebut didiamkan selama minimal 15 menit atau sampai terbentuk endapan setinggi $1 \mathrm{~cm}$. Sisa endapan di tabung tersebut ditambahkan air sampai ketinggian $2 \mathrm{~cm}$ dari mulut tabung kemudian diaduk dan ditempatkan pada tabung rak. Larutan didiamkan sampai terbentuk endapan minimal 15 menit. Cairan jernih dibuang dengan menyisakan endapan setinggi $1 \mathrm{~cm}$, lalu ditambahkan $\mathrm{NaOH}$ 10\% sebanyak 3 tetes, homogenisasi, dan ditambahkan air hingga setinggi $2 \mathrm{~cm}$ dari mulut tabung. Larutan tersebut dibiarkan selama 15 menit supaya terbentuk endapan. Cairan bagian jernih dibuang dengan menyisakan endapan setinggi $1 \mathrm{~cm}$, endapan tersebut ditetesi dengan methylene blue sebanyak 2 tetes dan membiarkannya selama beberapa menit. Larutan endapan feses dan methylene blue dituang pada cawan petri untuk kemudian diperiksa pada mikroskop binokuler (perbesaran 4 kali). Jika masih terlalu keruh ditambahkan beberapa $\mathrm{ml}$ air untuk mempermudah pengamatan pada cawan petri. Hasil pengamatan telur cacing dan oosista dianalisis dan didokumentasikan.

\section{HASIL DAN PEMBAHASAN}

Hasil penelitian menunjukkan dari 63 sampel feses sapi yang diperiksa 25 diantaranya terinfeksi cacing jenis Fasciola sp.,7 ekor Paramphistomum sp., 14 Strongyle dan 9 Coccidia. Telur cacing Fasciola sp. pada pemeriksaan Parfitt Bank akan telihat keemasan atau coklat, elips, mempunyai operkulum pada salah satu ujung, granular, dan berukuran panjang 130 sampai $145 \mu \mathrm{m}$ dengan lebar 70 sampai $90 \mu \mathrm{m}$. Telur paramphistomum berukuran panjang 125 sampai $180 \mu \mathrm{m}$ dengan lebar 75 sampai 103 $\mu \mathrm{m}$, berwarna kebiruan atau transparan, dibedakan dari telur fasciola dari warnanya yang kebiruan dan lebih ramping. Telur golongan strongyle berukuran panjang sekitar 62 sampai $95 \mu \mathrm{m}$ dengan lebar 36 sampai 50 
$\mu \mathrm{m}$, berbentuk elips, berdinding tipis, yang belum bersporulasi. Hasil pemeriksaan permukaan lembut, dan bersegmen. Coccidia feses disajikan pada Tabel 1.

pada feses sapi merupakan stadium oosista

Tabel 1. Data Hasil Pemeriksaan 63 Sampel Feses Sapi Potong di Dareah Aliran Sungai Progo

\begin{tabular}{lcc}
\hline \multicolumn{1}{c}{ Parameter } & $\begin{array}{c}\text { Sampel Terinfeksi/Total Sampel } \\
\text { (ekor) }\end{array}$ & $\begin{array}{c}\text { Persentase } \\
(\%)\end{array}$ \\
\hline Fasciola sp. & $25 / 63$ & 40 \\
Strongyle & $14 / 63$ & 22 \\
Coccidia & $9 / 63$ & 14 \\
Paramphistomum sp. & $7 / 63$ & 11 \\
Negatif & $8 / 63$ & 13 \\
\hline
\end{tabular}

Data hasil penelitian menunjukkan prevalensi parasit gastrointestinal terbesar adalah Fasciola sp. Dareah aliran Sungai Progo merupakan daerah penanaman hijauan ternak yang menjadi faktor predisposisi kejadian fasciolosis melalui adanya metaserkaria yang menempel pada rumput. Lahan hijauan di dareah aliran Sungai Progo berkaitan dengan tingginya infestasi parasit Fasciola $s p$. Hal tersebut disebabkan oleh kebiasaan peternak yang mencari rumput pada area berair. Cara peternak mencari rumput di dareah aliran sungai berpengaruh terhadap prevalensi fasciolosis karena metaserkaria sebagai stadium infektif Fasciola sp. didapatkan menempel pada rumput pada area basah. Kejadian fasciolasis banyak terjadi pada awal musim hujan karena pertumbuhan telur menjadi mirasidium cukup tinggi dan perkembangan di dalam tubuh siput mencapai tahap yang lengkap pada akhir musim kemarau (Aryandrie et al., 2015).

Prevalensi strongyle pada sapi daerah aliran Sungai Progo sebesar 22\%. Penularan cacing nematoda pada sapi ini tergolong mudah karena siklus hidupnya terjadi secara langsung tanpa memerlukan hospes perantara (Hamid et al., 2016).

Prevalensi Coccidiosis pada sapi daerah aliran Sungai Progo sebesar 14\%. Coccidia merupakan protozoa pada saluran pencernaan yang dapat menyebabkan diare. Beberapa spesies yang ditemukan pada kejadian Coccidiosis di Jawa Tengah di antaranya adalah Eimeria bovis, E. auburnensis, E. bukidnonensis, E. canadaensis, E. zurnii and E. cylindrical (Hamid et l., 2016).

Paramphistomum merupakan parasit golongan trematoda yang berlokasi di dalam rumen. Siklus hidup cacing ini memerlukan hospes intermedier yaitu siput Lymnea rubiginosa. Prevalensi paramphistomum pada sapi di daerah aliran Sungai Progo sebesar 11\%. Hal ini berkaitan dengan lokasi dari kandang sapi di aliran sungai dimana rumput yang diberikan berasal dari lahan di dareah aliran sungai. Hal tersebut dapat menyebabkan penularan cacing Paramphistomum sp. melalui stadium metaserkaria yang menempel pada rumput sebagai stadium infektif. Sapi betina berpotensi terserang Paramphistomum $s p$. 
sebesar 1,97 kali dibandingkan sapi jantan (Lestari, et al. 2017).

\section{KESIMPULAN}

Prevalensi parasit gastrointestinal tertinggi pada sapi di daerah aliran Sungai Progo mulai dari yang terbesar adalah Fasciola sp. (40\%), Strongyle (22\%), Coccidia (14\%), Paramphistomum sp. (11\%).

\section{DAFTAR PUSTAKA}

Arsani, N.M., I.K. Mastra, N.K.H Saraswati, Yunanto, dan I.G.M Sutawijaya. 2015. Epidemiologi helminthiasis pada ternak sapi di Provinsi Bali. Buletin Balai Besar Veteriner Denpasar. 27(87).

Aryandrie, D.F., P.E. Santosa, and S. Suharyati. 2015. Tingkat infestasi cacing hati pada Sapi Bali di Kecamatan Sukoharjo Kabupaten Pringsewu Provinsi Lampung. Jurnal Ilmiah Peternakan Terpadu. 3(3): 134-139.

Darmin, S., P.F. Yuliza, dan M. Sirupang. 2016. Prevalensi Paramphistomiasis pada Sapi Bali di Kecamatan Libureng, Kabupaten Bone. Jurnal Ilmu-Ilmu Peternakan. 2: 149-161.

Das, Meena, D.K. Deka, S. Islam, P.C. Sarmah, and K. Bhattacharjee. 2016. Gastrointestinal nematode larvae in the grazing land of cattle in Guwahati Assam. Veterinary World. 9: 1343-1347.

Hamid, P.H., Y.P. Kristianingrum, J. Prastowo, and L.M.R. Silva. 2016. Gastrointestinal parasites of cattle in Central Java. American Journal of Animal and Veterinary Science. 11(3): 119-124.

Handayani, P., P.E. Santosa, dan Siswanto. 2015. Tingkat infestasi cacing saluran pencernaan pada Sapi Bali di Kecamatan Sukoharjo Kabupaten Pringsewu Provinsi Lampung. Jurnal Ilmiah Peternakan Terpadu. 3(3): 127-133.

Huang, C., L. Wang, C. Pan, C. Yang, and C. Lai. 2014. Investigation of gastrointestinal parasites of dairy cattle around Taiwan. Journal of Microbiology, Immunology, and Infection. 47(1): 70-74.

Junaidi, M., P. Sambodo, dan D. Nurhayati. 2014. Prevalensi nematoda pada Sapi Bali di Kabupaten Manokwari. Buletin Veteriner Udayana. 9(2): 195-201.

Karim, W.A., A. Farajallah, and B. Suryobroto. 2016. Exploration and prevalence of gastrointestinal worm in buffalo from West Java, Central Java, East Java and Lombok, Indonesia. Aceh Journal of Animal Science. 1(1): 1-15.

Lestari, A.A.I.T.J., I.B.W. Adnyana, dan I.B.M. Oka. 2017. Prevalensi dan gambaran patologi infestasi cacing Paramphistomum spp. pada rumen Sapi Bali yang dipotong di Rumah Potong Hewan (RPH) Kota Denpasar. Indonesia Medicus Veterinus. 6(1): 20-29.

Marskole, P., Y. Verma, A.K. Dixit, and M. Swamy. 2016. Prevalence and burden of gastrointestinal parasites in cattle and buffaloes in Jabalpur, India. Veterinary World. 9(11): 1214-1217.

Nnabuife, H.E., A.D. Dakul, G.I. Dogo, O.K. Egwu, P.R. Weka, I.N. Ogo, E.O. Onovoh, B.O. Obaloto. 2013. A study on helminthiasis of cattle herds in Kachia Grazing Reserve (KGR) of Kaduna State , Nigeria. Veterinary World. 6: 936-40.

Virgi, A.R.J., S. Susilowati, dan S. Joesdarto. 2015. Pengaruh tatalaksana kandang terhadap infeksi helminthiasis saluran pencernaan pada pedet peranakan Simental dan Limousin di Kecamatan Yosowilangun Lumajang. Agroveteriner 3(2): 114-200.

Widyaningrum,Y., D. Ratnawati, dan T.A. Sulistya. 2015. Helminthiasis saluran pencernaan pada pedet Sapi Ongole di lokasi penelitian sapi potong. Seminar Nasional Teknologi Pertanian dan Veteriner. http://peternakan.litbang. pertanian.go.id/fullteks/semnas/pro1436.pdf?secure $=1$. Diakses tanggal 20 Desember 2017. 